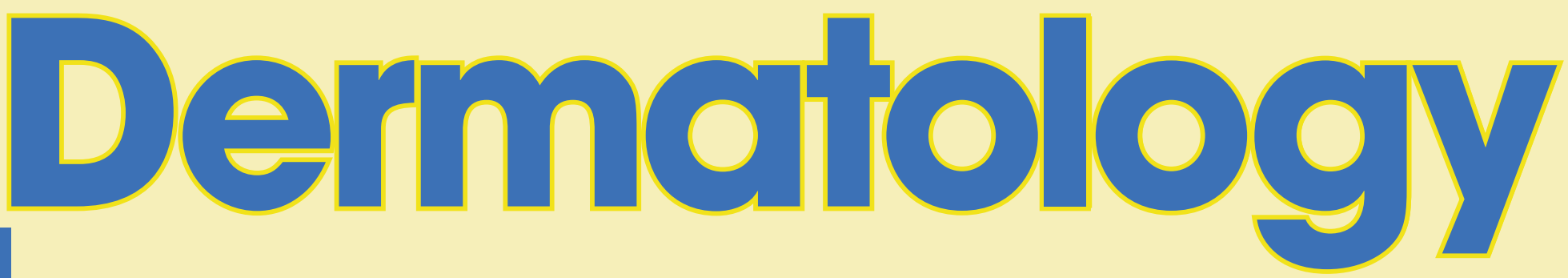

Highlights

- Propranolol for the Treatment of Infantile Hemangioma

- TNF Haplotypes in Acne Vulgaris

- Ustekinumab for Scalp Psoriasis

- Socks for Improving Plantar Pustulosis

- Protection Roles of Sweat in the Skin

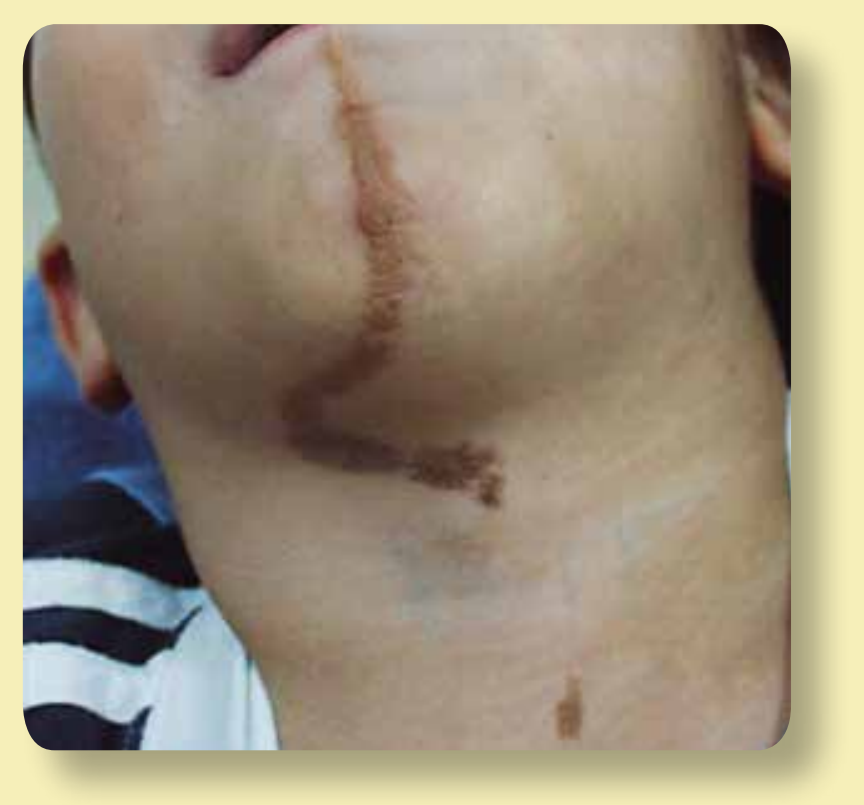




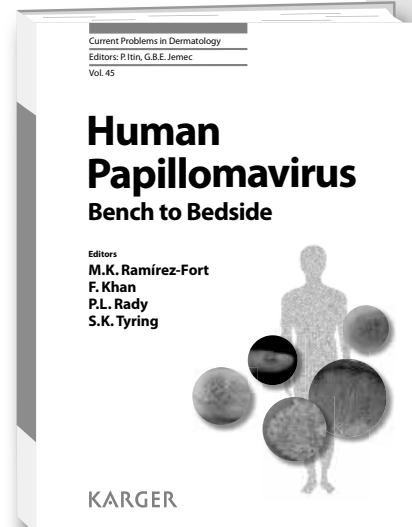

\title{
Human Papillomavirus
}

\section{Bench to Bedside}

\author{
Editors \\ Marigdalia K. Ramírez-Fort \\ Farhan Khan \\ Peter L. Rady \\ Stephen K. Tyring
}

Human Papillomavirus

Bench to Bedside

Editors: Ramírez-Fort, M.K. (Houston, Tex.);

Khan, F. (Houston, Tex.); Rady, P.L. (Houston, Tex.);

Tyring, S.K. (Houston, Tex.)

VIII + 272 p., 61 fig., 55 in color, 15 tab., 2014

CHF 219.- / EUR 183.- / USD 258.00 (hard cover)

CHF 263.- / EUR 220.- / USD 310.00 (online)

Online version for institutional purchase

EUR price for Germany, USD price for USA and

Latin America only

ISBN 978-3-318-02526-2 (hard cover)

e-ISBN 978-3-318-02527-9

Current Problems in Dermatology, Vol. 45 Series Editors: Itin, P. (Basel),

Jemec, G.B.E. (Roskilde)

ISSN 1421-5721 / e-ISSN 1662-2944

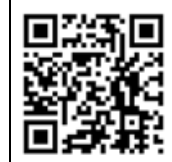

Dear Librarian

I have reviewed this publication and would like to recommend it for our library. Recommended by:

Department:

Date:

Signature:

Orders may be placed with any bookshop
Human papillomavirus (HPV) infection transcends multiple fields of science and medicine. The management of HPV-related disease is demanding and often requires a persistent multimodal approach involving various medical disciplines.

In this volume, experts present a comprehensive view of HPV research with an emphasis on clinical presentations, diagnosis, management and vaccine development. The state of the art in molecular biology is provided in addition to discussions on clinical morphology and the utility of dermatoscopy in identifying HPV disease. In a multidisciplinary approach to dermatological, plastic and reconstructive, gynecological, otolaryngological and colorectal management, different treatment strategies are highlighted. Finally, Dr. Neil Christensen discusses viral immunology, and the difficulties and successes in the development of an HPV vaccine.

Bringing together basic science and clinical information on HPV, this book is an excellent resource and reference for all researchers and clinicians who encounter human papillomavirus-related disease.

\section{Contents}

Foreword: Brodell, R.T.

\section{Introduction}

- Human Papillomavirus Genomics: Past, Present and Future: Harari, A.; Chen, Z.; Burk, R.D.

\section{Molecular Biology and Pathogenesis}

- The Biology of Human Papillomaviruses: Nguyen, H.P.; Ramírez-Fort, M.K.; Rady, P.L.

- Viral Oncogenesis: Doan, H.Q.; Ramírez-Fort, M.K.; Rady, P.L.

- Pathogenesis of Infection by

Human Papillomavirus: Brendle, S.A.; Bywaters, S.M.; Christensen, N.D.

- Host Responses to Infection with

Human Papillomavirus: Stanley, M.A.; Sterling, J.C.

\section{Epidemiology and Clinical Manifestations}

- The Epidemiology of Human Papillomaviruses: Nyitray, A.G.; lannacone, M.R.

- Cutaneous Human Papillomavirus Infection: Manifestations and Diagnosis: Tschandl, P.; Rosendahl, C.; Kittler, H.

- Genitoanal Human Papillomavirus Infection and Associated Neoplasias: Gross, G.

- Epidermodysplasia Verruciformis: Burger, B.; Itin, P.H. - Human Papillomavirus Infections of the Oral

Mucosa and Upper Respiratory Tract: Nguyen, H.P.; McNiece, K.L.; Duong, A.A.; Khan, F.

- Human Papillomavirus and Immunosuppression: Wieland, U.; Kreuter, A.; Pfister, $\mathrm{H}$.

\section{Laboratory Diagnosis}

- Laboratory Diagnosis of Human Papillomavirus Infection: Ikenberg, $\mathbf{H}$.

\section{Treatment and Prevention}

- Management of Cutaneous Human Papillomavirus Infection: Pharmacotherapies: Ramírez-Fort, M.K.; Au, S.-C.; Javed, S.A.; Loo, D.S.

- Management of Cutaneous Human Papillomavirus Infection: Surgery: Ramírez-Fort, M.K.; Sam, H.; Manders, E.K.

- Management of Cutaneous Human Papillomavirus Infection in Immunocompromised Patients: Varada, S.; Posnick, M.; Alessa, D; Ramírez-Fort, M.K.

- Management of Human Papillomavirus-Related Gynecological Malignancies: Heinzelmann-Schwarz, V.A.; Kind, A.B.; Jacob, F.

- Management of Human Papillomavirus-Related Anal and Colon Cancer: Yen Moore, A.; Tong, L.X.; Moore, $\mathrm{T}$.

- Management of Human Papillomavirus-Related Head and Neck Cancer: Coughlin, A.M.; Qiu, S.; Underbrink, M.P.

- Vaccines and Immunization against Human Papillomavirus: Christensen, N.D.; Budgeon, L.R.

Author Index / Subject Index 


\section{Dermatology}

An International Journal founded as

'Dermatologische Zeitschrift' by Oskar Lassar (1893-1907)

Continued by Erich Hoffmann (1908-1938), continued as 'Dermatologica' (1939-1991),

by Wilhelm Lutz (1939-1958), Rudolf Schuppli (1959-1985)

\section{Editor-in-Chief}

\section{J.-H. Saurat, Geneva}

\section{Deputy Editor}

\section{Lipsker, Strasbourg}

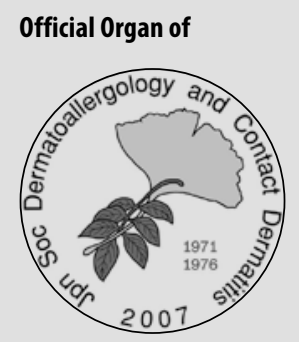

Swiss Society for Dermatology and Venereology

Schweizerische Gesellschaft für Dermatologie und Venerologie Société Suisse de Dermatologie et Vénéréologie

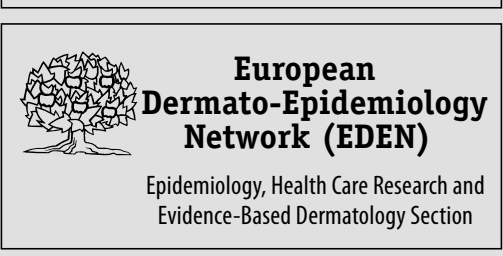

Affiliated with

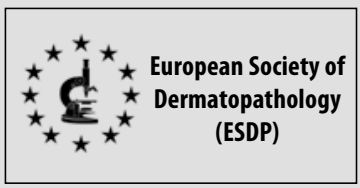

\section{Associate Editors}

G. Argenziano, Reggio Emilia

M. Augustin, Hamburg

W.H. Boehncke, Geneve

L. Borradori, Bern

R.P. Braun, Zürich

R. Cerio, London

L. Cerroni, Graz

O. Chosidow, Créteil

A. Dupuy, Rennes

J.W. Fluhr, Berlin

L. French, Zürich

F. Furukawa, Wakayama

M. Gilliet, Lausanne

A.K. Gupta, London, Ont.

R. Happle, Freiburg

R.J. Hay, London

P. Itin, Basel

G. Kaya, Geneva

R.G.B. Langley, Halifax, N.S.

J.M. Mascaro, Jr., Barcelona

K. Matsunaga, Nagoya

Y. Miyachi, Kyoto

L. Naldi, Bergamo

F. Nestle, London

C. Paul, Toulouse

T. Shiohara, Tokyo

Th. Simonart, Brussels

H.P. Soyer, Brisbane, Qld.

L. Thomas, Lyon

R.M. Trueb, Zürich

T.J. Yoon, Jinju

Ch.C. Zouboulis, Dessau

\section{International Advisory Board}

S.M. Aiba, Sendai

S. Aractingi, Paris

S. Chimenti, Rome

B. Cribier, Strasbourg

C. Gelmetti, Milano

A. von Graevenitz, Kilchberg

H. Hönigsmann, Vienna

P. Joly, Rouen

S. Karpati, Budapest

A.D. Katsambas, Athens

J.-M. Lachapelle, Montigny-le-Tilleul

M.C. Mihm, Jr., Boston, Mass.

G.E. Piérard, Liège

G. Plewig, Munich

F.C. Powell, Dublin

A.-A. Ramelet, Lausanne

J. Revuz, Créteil

J. Ring, Munich

M. Röcken, Tübingen

R.A. Schwartz, Newark, N.J.

N. Stavrianeas, Athens

H. Traupe, Münster

A. Vahlquist, Uppsala

D.T. Woodley, Los Angeles, Calif. 


\section{Dermatology}

\section{Submission}

Only original papers written in English should be sent to:

www.karger.com/drm
Prof. J.-H. Saurat
S. Karger AG
Editorial Office 'Dermatology'
PO Box
CH-4009 Basel (Switzerland)
Tel. +41 613061357
Fax +4161306 1434
E-Mail drm@karger.com

\section{Conditions}

All manuscripts are subject to editorial review. Manuscripts are received with the explicit understanding that they are not under simultaneous consideration by any other publication. Submission of an article for publication implies transfer of the copyright from the author to the publisher upon acceptance. Accepted papers become the permanent property of Dermatology and may not be reproduced by any means, in whole or in part, without the written consent of the publisher. It is the author's responsibility to obtain permission to reproduce illustrations, tables, etc. from other publications.

\section{Sections}

The journal consists of the following sections:

- Editorials

- Original Papers

- Case and Review (This section contains case reports extended with literature reviews.)

- Case Reports

- Letters to Dermatology

- Rapid Communication/Hot Topics

We proudly publish the Newsletter of the International League of Dermatological Societies (ILDS).

\section{Topics}

Please submit papers of the following topics:

- Clinical and Laboratory Studies

- Dermatopathology

- Dermatosurgery and Related Interventional

Techniques

- Imaging Techniques

- Evidence-Based Dermatology

- Pharmacology and Treatment

\section{Conflicts of Interest}

Authors are required to disclose any sponsorship or funding arrangements relating to their research and all authors should disclose any possible conflicts of interest. Conflict of interest statements will be published at the end of the article.

\section{Plagiarism Policy}

Whether intentional or not, plagiarism is a serious violation. We define plagiarism as a case in which a paper reproduces another work with at least $25 \%$ similarity and without citation.

If evidence of plagiarism is found before/after acceptance or after publication of the paper, the au- thor will be offered a chance for rebuttal. If the arguments are not found to be satisfactory, the manuscript will be retracted and the author sanctioned from publishing papers for a period to be determined by the responsible Editor(s).

\section{Ethics}

Published research must comply with the guidelines for human studies and animal welfare regulations. Authors should state that subjects have given their informed consent and that the study protocol has been approved by the institute's committee on human research. Further, they should also state that animal experiments conform to institutional standards.

\section{Rapid Communications/Hot Topics}

Authors may apply to have their paper treated as a rapid communication. Condition for this is a brief definite report of important results. Final decision whether a paper will be published as a rapid communication will be made by the Editors. A publication time of three months after acceptance is intended.

\section{Arrangement}

Papers should comprise approximately 13 pages including figures, tables and references. For technical details please refer to: www.karger.com/electronic_submission.

Title page: The first page of each paper should indicate the title, the authors' names, the institute where the work was conducted, and a short title for use as running head.

Full address: The exact postal address of the corresponding author complete with postal code must be given at the bottom of the title page. Please also supply phone and fax numbers, as well as e-mail address.

Key words: Please supply 3-10 key words in English that reflect the content of the paper.

Abstract: Normally each paper needs an abstract of not more than 150 words. It should contain the following information: purpose of the study, procedures, results, conclusions and message of the paper. Abstracts submitted for publication in the section Original Papers should be structured as follows: Background: What is the major problem that prompted the study?

Objective: What is the purpose of the study? Methods: How was the study performed? Results: Most important findings? Conclusion: Most important conclusion?

Footnotes: Avoid footnotes. When essential, they are numbered consecutively and typed at the foot of the appropriate page.

Tables and illustrations: Tables and illustrations (both numbered in Arabic numerals) should be stored in separate files. Tables require a heading and figures a legend, also prepared on a separate file. When possible, group several illustrations in one block for reproduction (max. size $180 \times 223 \mathrm{~mm}$ ) or provide crop marks. $\mathrm{B} / \mathrm{w}$ half-tone and color illustrations must have a final resolution of $300 \mathrm{dpi}$ after scaling, line drawings one of 800-1,200 dpi. For further details please refer to the Submission Website at www.karger.com/drm.

Color illustrations: During the review process, the decision will be made as to which color illustrations of a manuscript can be reproduced free of charge. Authors will be informed of this at the time of acceptance of their paper. Otherwise, these illustrations will be reproduced at the author's expense. Up to 6 color illustrations per page can be integrated into the text at the special price of CHF 800 .- per page.

Anonymity in Case Reports: Authors should preserve patients' anonymity both in the text and figures, in the case that patients might be identified, authors should obtain his (her) informed consent.

References: In the text identify references by Arabic numerals [in square brackets]. Material submitted for publication but not yet accepted should be noted as [unpublished data] and not be included in the reference list. The list of references should include only those publications which are cited in the text. Avoid using abstracts and posters as references. If necessary list as footnotes in standard reference format, followed by the designation '(abstr.)' or '(poster)'. For posters, add the details of the meeting where presented. Do not alphabetize; number references in the order in which they are first mentioned in the text. The surnames of the authors followed by initials should be given. There should be no punctuation other than a comma to separate the authors. Preferably, please cite all authors. Abbreviate journal names according to the Index Medicus system. Also see International Committee of Medical Journal Editors: Uniform requirements for manuscripts submitted to biomedical journals (www.icmje.org).

\section{Examples}

(a) Papers published in periodicals: Chatel JM, Bernard $\mathrm{H}$, Orson FM: Isolation and characterization of two complete Ara h 2 isoforms cDNA. Int Arch Allergy Immunol 2003;131:14-18.

(b) Papers published only with DOI numbers:

Theoharides TC, Boucher W, Spear K: Serum interleukin-6 reflects disease severity and osteoporosis in mastocytosis patients. Int Arch Allergy Immunol DOI: $10.1159 / 000063858$.

(c) Monographs: Matthews DE, Farewell VT: Using and Understanding Medical Statistics, ed 3, revised. Basel, Karger, 1996.

(d) Edited books: DuBois RN: Cyclooxygenase-2 and colorectal cancer; in Dannenberg AJ, Dubois RN (eds): COX-2. Prog Exp Tum Res. Basel, Karger, 2003, vol 37, pp 124-137.

Reference Management Software: Use of EndNote is recommended for easy management and formatting of citations and reference lists.

\section{Digital Object Identifier (DOI)}

S. Karger Publishers supports DOIs as unique identifiers for articles. A DOI number will be printed on

\section{KARGER}

E-Mail karger@karger.com www.karger.com
(C) 2014 S. Karger AG, Basel 
the title page of each article. DOIs can be useful in the future for identifying and citing articles published online without volume or issue information. More information can be found at www.doi.org.

\section{Supplementary Material}

Supplementary material is restricted to additional data that are not necessary for the scientific integrity and conclusions of the paper. Please note that all supplementary files will undergo editorial review and should be submitted together with the original manuscript. The Editors reserve the right to limit the scope and length of the supplementary material. Supplementary material must meet production quality standards for Web publication without the need for any modification or editing. In general, supplementary files should not exceed $10 \mathrm{Mb}$ in size. All figures and tables should have titles and legends and all files should be supplied separately and named clearly. Acceptable files and formats are: Word or PDF files, Excel spreadsheets (only if the data cannot be converted properly to a PDF file), and video files (.mov, .avi, .mpeg)

\section{Author's Choice ${ }^{\mathrm{TM}}$}

Karger's Author's Choice ${ }^{\mathrm{TM}}$ service broadens the reach of your article and gives all users worldwide free and full access for reading, downloading and printing at www.karger.com. The option is available for a one-time fee of CHF 3,000.-, which is a permissible cost in grant allocation. More information can be found at www.karger.com/authors_choice.

\section{NIH-Funded Research}

The U.S. National Institutes of Health (NIH) mandates under the NIH Public Access Policy that final, peer-reviewed manuscripts appear in its digital database within 12 months of the official publication date. As a service to authors, Karger submits your manuscript on your behalf to PubMed Central (PMC) immediately upon publication. It usually receives a PMCID within approximately a month and will appear in PMC after 12 months. For those selecting our premium Author's Choice ${ }^{\mathrm{TM}}$ service, the usual embargo will be overridden, accelerating the accessibility of your work.

\section{Self-Archiving}

Karger permits authors to archive their pre-prints (i.e. pre-refereeing) or post-prints (i.e. final draft post-refereeing) on their personal or institution's servers, provided the following conditions are met: Articles may not be used for commercial purposes, must be linked to the publisher's version, and must acknowledge the publisher's copyright. Authors selecting Karger's Author's Choice ${ }^{\mathrm{TM}}$ feature, however, are also permitted to archive the final, published version of their article, which includes copyediting and design improvements as well as citation links.

\section{Page Charges}

There are no page charges for papers of 4 or fewer printed pages (including tables, illustrations and references). Each additional complete or partial page is charged to the author at CHF 325.-. The allotted size of 4 printed pages is equal to approx. 13 manuscript pages (including tables, illustrations and references).

\section{Proofs}

Unless indicated otherwise, proofs are sent to the corresponding author and should be returned with the least possible delay. Alterations other than the correction of printer's errors are charged to the author.

\section{E-pub First}

All articles are published electronically ahead of print with a DOI number and are supplemented later with the definite reference of the printed version. The articles become available immediately after the authors' approval to publication, with the added advantage of being citable much earlier than in print. Authors can influence the time of appearance by promptly returning the proofs.

\section{Reprints}

Order forms and a price list are sent with the proofs. Orders submitted after the issue is printed are subject to considerably higher prices.

2011 Impact factor: 2.053

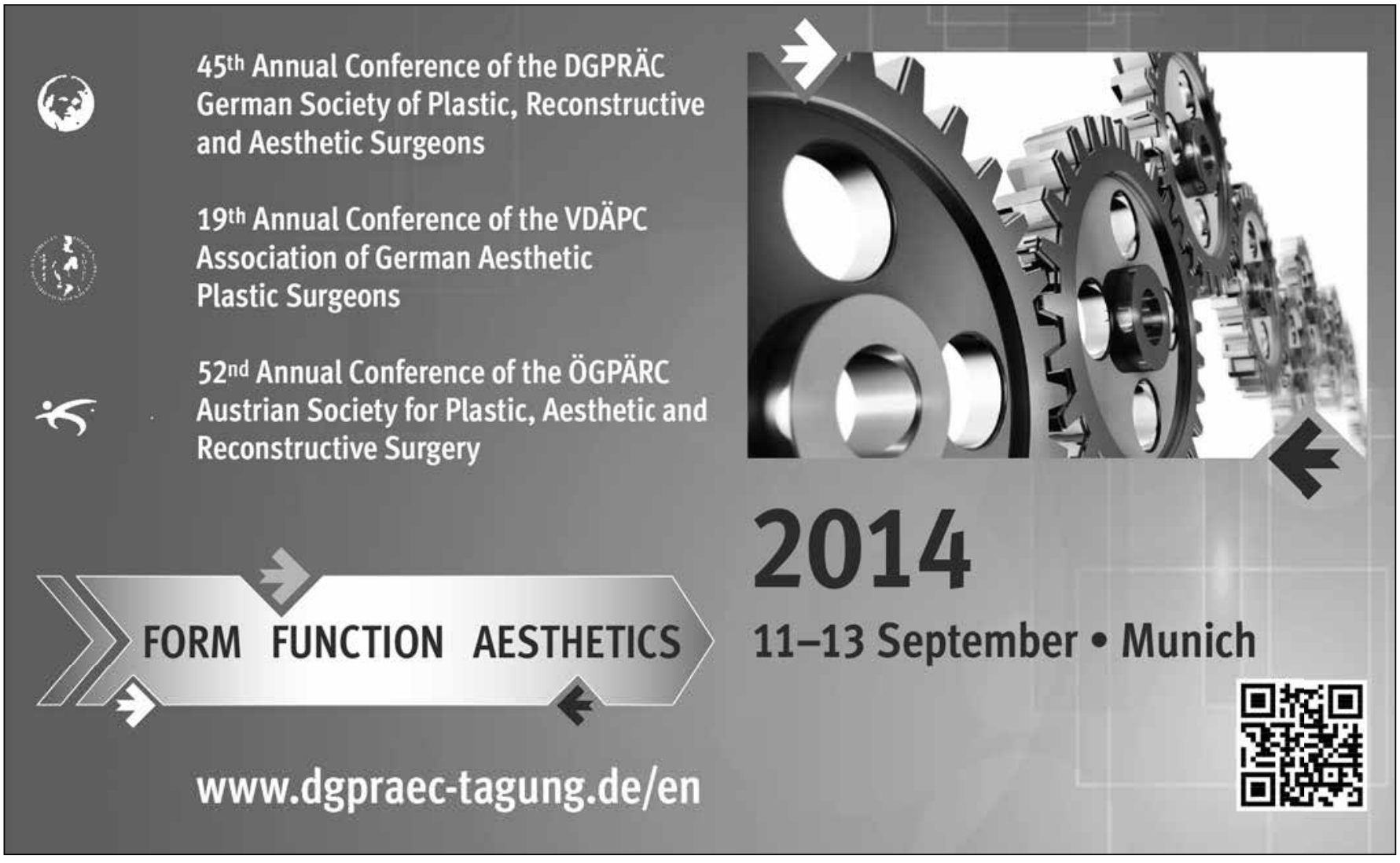

F14390

\section{KARGER}

E-Mail karger@karger.com www.karger.com
(C) 2014 S. Karger AG, Basel

The Guidelines for Authors are available at:

www.karger.com/drm_Guidelines 


\section{Dermatology}

ISSN Print Edition: 1018-8665

ISSN Online Edition: 1421-9832

Journal Homepage: www.karger.com/drm

Publication Data: Dermatology is published 8 times a year. Volumes $228-229$, each with 4 issues, appear in 2014 .

Copyright: (c) 2014 S. Karger AG, Basel (Switzerland). All rights reserved. No part of this publication may be translated into other languages, reproduced or utilized in any form or by any means, electronic or mechanical, including photocopying, recording, microcopying, or by any information storage and retrieval system, without permission in writing from the publisher or, in the case of photocopying, direct payment of a specified fee to the Copyright Clearance Center.

Disclaimer: The statements, opinions and data contained in this publication are solely those of the individual authors and contributors and not of the publisher and the editor(s). The appearance of advertisements in the journal is not a warranty, endorsement, or approval of the products or services advertised or of their effectiveness, quality or safety. The publisher and the editor(s) disclaim responsibility for any injury to persons or property resulting from any ideas, methods, instructions or products referred to in the content or advertisements.
Subscription Rates: Subscriptions run for a full calendar year. Prices are given per year. Personal subscription:

Print or Online

CHF 1460.-

EUR 1198.-

USD 1460.00

Print+Online combined CHF 1556.-

EUR 1276.-

USD 1556.00

postage and handling (added to print and print+online)

CHF 59.20 Europe, CHF 86.40 Overseas

EUR 48.-

USD 78.40

Institutional subscription

Print or Onlin

Print+Online combined

CHF 2920.-

EUR 2394.-

CHF 3212.-

USD 2920.00

USD 3212.00

postage and handling (added to print and print+online)

CHF 74.- Europe, CHF 108.- Overseas

EUR 60.-

USD 98.00

Discount subscription prices:

For members of Dermatology Societies.
Back Volumes and Single Issues: Information on availability and prices of single print issues and print or electronic back volumes can be obtained from Customer Service atservice@karger.com.

Bibliographic Indices: This journal is regularly listed in bibliographic services, including Current Contents ${ }^{\circledR}$ and PubMed/MEDLINE.

Photocopying: This journal has been registered with the Copyright Clearance Center (CCC), as indicated by the code appearing on the first page of each article. For readers in the US, this code signals consent for copying of articles for personal or internal use, or for the personal or internal use of specific clients, provided that the stated fee is paid per copy directly to

Copyright Clearance Center Inc.

222 Rosewood Drive

Danvers, MA 01923 (USA)

A copy of the first page of the article must accompany payment. Consent does not extend to copying for general distribution, for promotion, for creating new works, or for resale. In these cases, specific written permission must be obtained from the copyright owner,

S. Karger AG, P.O. Box

CH-4009 Basel (Switzerland).

\section{Subscription Orders:}

Orders can be placed at agencies,

bookstores, directly with the Publisher

\section{S. Karger AG}

Medical and Scientific Publishers

Allschwilerstrasse 10

CH-4009 Basel

Switzerland

t: +41613061111

f: +41613061234

e: karger@karger.com

w: www.karger.com

(for courier services only:

Allschwilerstrasse 10

CH-4055 Basel)

or further Karger offices
or representatives:
Germany
S. Karger GmbH
Postfach
79095 Freiburg
Deutschland
(Hausadresse: Wilhelmstrasse 20A,
79098 Freiburg)
t: +49 76145 20 70
f: +49 761 4520714
e: information@karger.de
w: www.karger.de
Japan
Karger Japan, Inc.
Shiba Daimon Asahi Bldg. 2F
1-2-23 Shiba Daimon
Minato-ku
Tokyo $105-0012$
Japan
t: +81364356242
f: +81 364356244
e: publisher@karger.jp
w: www.karger.jp

USA

S. Karger Publishers, Inc.

26 West Avon Road

P.O. Box 529

Unionville, CT 06085

USA

Toll free: +18008285479

t: +18606757834

f: +18606757302

e: karger@snet.net

France

Enter \& Read

Albertine Luginbuh

23, rue du Départ, boite 37

75014 Paris

France

t: $+33(0) 681047685$

e: albertineluginbuhl@orange.fr

South East Asia, China and Taiwan

Karger Regional Office (Malaysia)

CEO Suite Kuala Lumpur

Quill 7, 27th Floor

alan Stesen Sentral 5

KL Sentral

Kuala Lumpur 50470

Malaysia

t: +60327766803

f: +60327766999

e: service@karger.cn

\section{Karger China}

West/5F, China Life Towe

No.16, Chao Wai Street

Chaoyang District

Beijing 100020

China

t: +86105877 1408

f: +861058771120

e: service@karger.cn; r.chew@karger.cn

w: www.karger.cn

India, Bangladesh, Sri Lanka

Karger India

Plot No. 17, Yusuf Sarai Market

B.L. Glass Building, 2nd Floor

Sri Aurobindo Marg

New Delhi 110016

India

t: +911146029633

f: +911146029634

c: +919891052128

e: rkumar@kargerindia.com

w: www.karger.com

Change of Address:

Both old and new address should be sent

to the subscription source.

\section{KARGER}

E-Mail karger@karger.com www.karger.com
(C) 2014 S. Karger AG, Basel

The Guidelines for Authors are available at: www.karger.com/drm_Guidelines 


\section{Contents}

See the journal website for contents

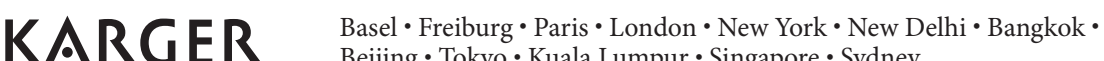
Beijing $\cdot$ Tokyo $\cdot$ Kuala Lumpur $\cdot$ Singapore $\cdot$ Sydney 
Zürcher Dermatologische Fortbildungstage

\title{
Zürcher Dermatologische Fortbildungstage
}

\author{
25. - 28. Juni 2014, Kongresshaus Zürich
}

www.zhdermfortbildungstage.ch

\section{Schwerpunkt 2014}

Regionale Dermatosen

\section{Eingeladene Gastreferenten (Stand Mitte Februar 2014)}

Pemphigoiderkrankungen

Prof. Dr. Michael Hertl

Pemphiguserkrankungen

Prof. Dr. Detlef Zillikens

Intertrigo-Erkrankungen

Dr. Siegfried Borelli

Onkologische Augenlidchirurgie

und Orbitachirurgie

Dr. Karla Chaloupka
Erkrankungen bei dunkler Haut

Dr. Benedikt Göschke

Pruritus ani - Therapien

Dr. Andreas-Paul Müller

Schwere Medikamentenreaktionen:

Mechanismus und Genetik

Prof. Dr. Werner Pichler

Chirurgie - What's New?

Dr. André Skaria 


\section{Agenda}

The leading subjects on aesthetic surgery and cosmetic dermatology

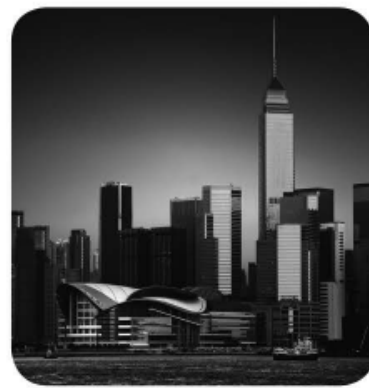

IMCAS ASWA

HONG KONG

AUGUST 1 to 3,2014

Hong Kong Convention Center
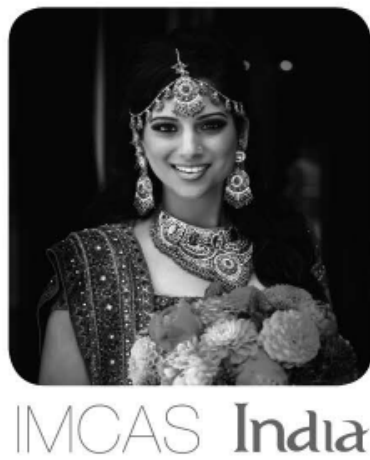

GOA

NOVEMBER 14 to 16,2014

Radisson Blu Resort Cavelossim Beach
FEED YOUR SCIENCE CRANING

AESTHETIC SURGERY \& COSMETIC DERMATOLOGY

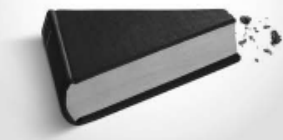

$\wedge \wedge 17^{\text {th }}$ Annual

PARIS

JAN.29 to FEB.1, 2015

Palais des Congrès de Paris

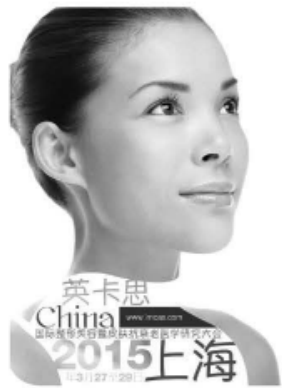

$\| \wedge \circlearrowleft \circlearrowleft$ Cima

SHANGHAI

MARCH 27 to 29,2015

Kerry Pudong Convention Center

\section{Head to imcas.com!}

- Create and update your member account with your picture and latest biostatement

- Watch KOL interviews on IMCAS TV

- IMCAS Live! Share and comment the latest news of the market on wuw.imcas.com/en/live
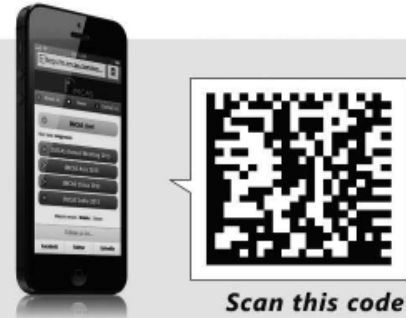

Scan this code

with your

smartphone

- Stay updated with the latest information on the aesthetic medical market

to imcas.com!

- Debate with your colleagues on a hot topic updated each week

- Register to IMCAS meetings

- Send a message to a speaker

- Download updated IMCAS congress programs

- Submit an abstract for all IMCAS conferences (Paris, Asia, China, India)

- Check out the agenda of the best meetings worldwide

- Have a look on IMCAS humanitarian mission directory

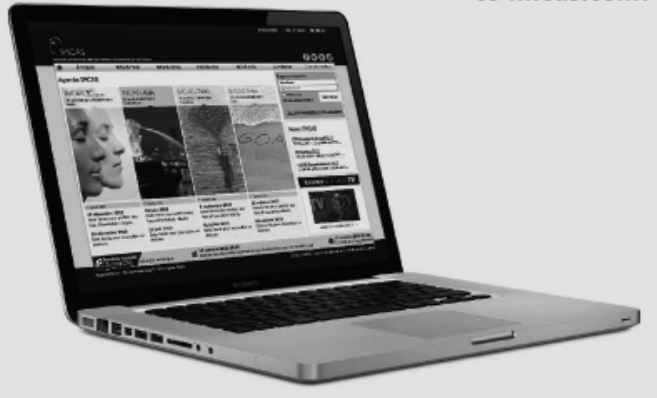

- E-learning with more than 200 videos on lasers, injectables, etc.

Paris Head Office:

8, rue Foucault-75116 Paris - France

\section{Hong Kong Head Quarter:}

Suite 1801-5, 18/F, Tower 2,

China Hong Kong City, 33 Canton Road

TST, Kowloon, Hong Kong SAR
+ +33140738282

툼 +33140709240 contact@imcas.com

www.imcas.com

follow us on Facebook \& Twitter twitter.com/imcascongress 


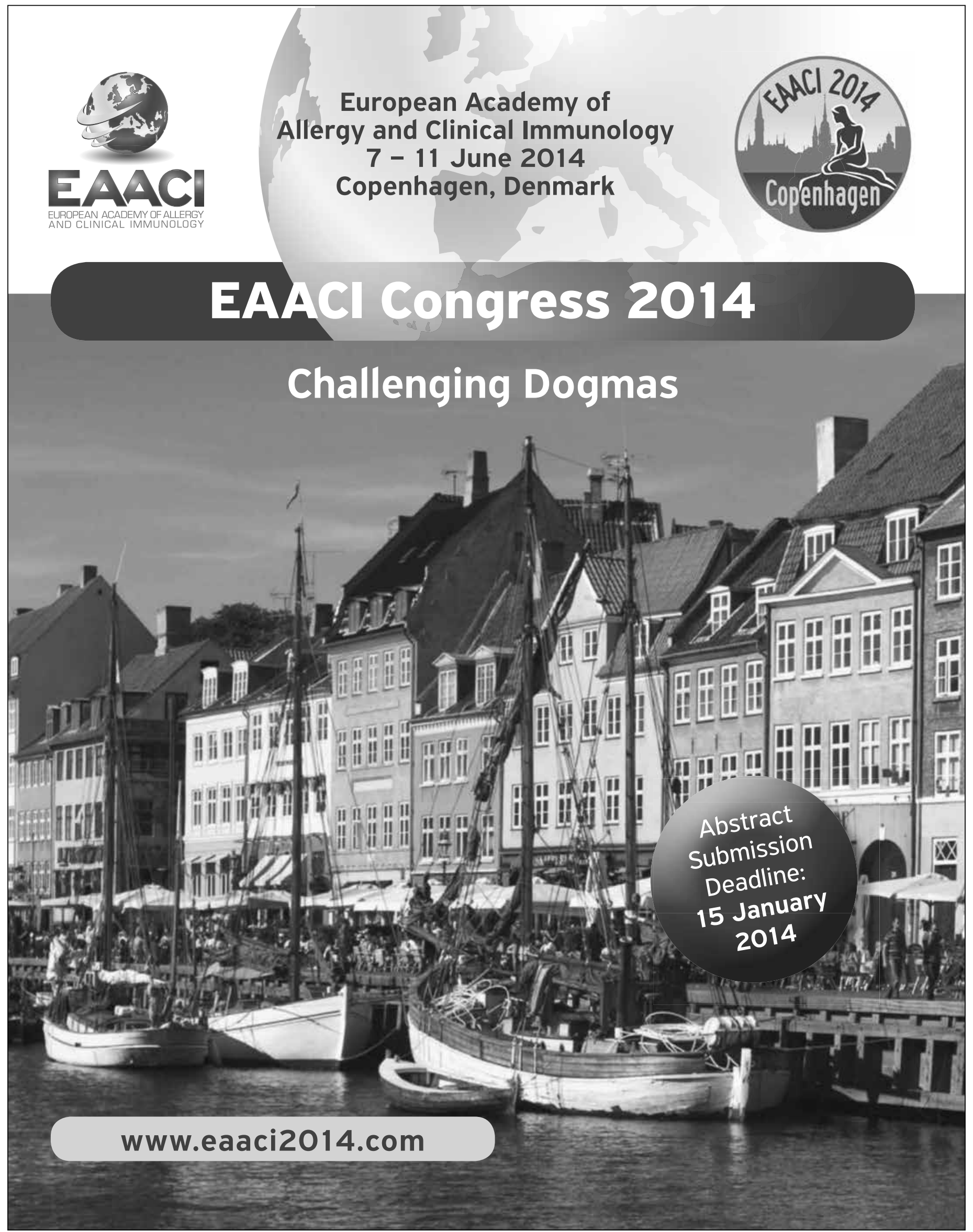




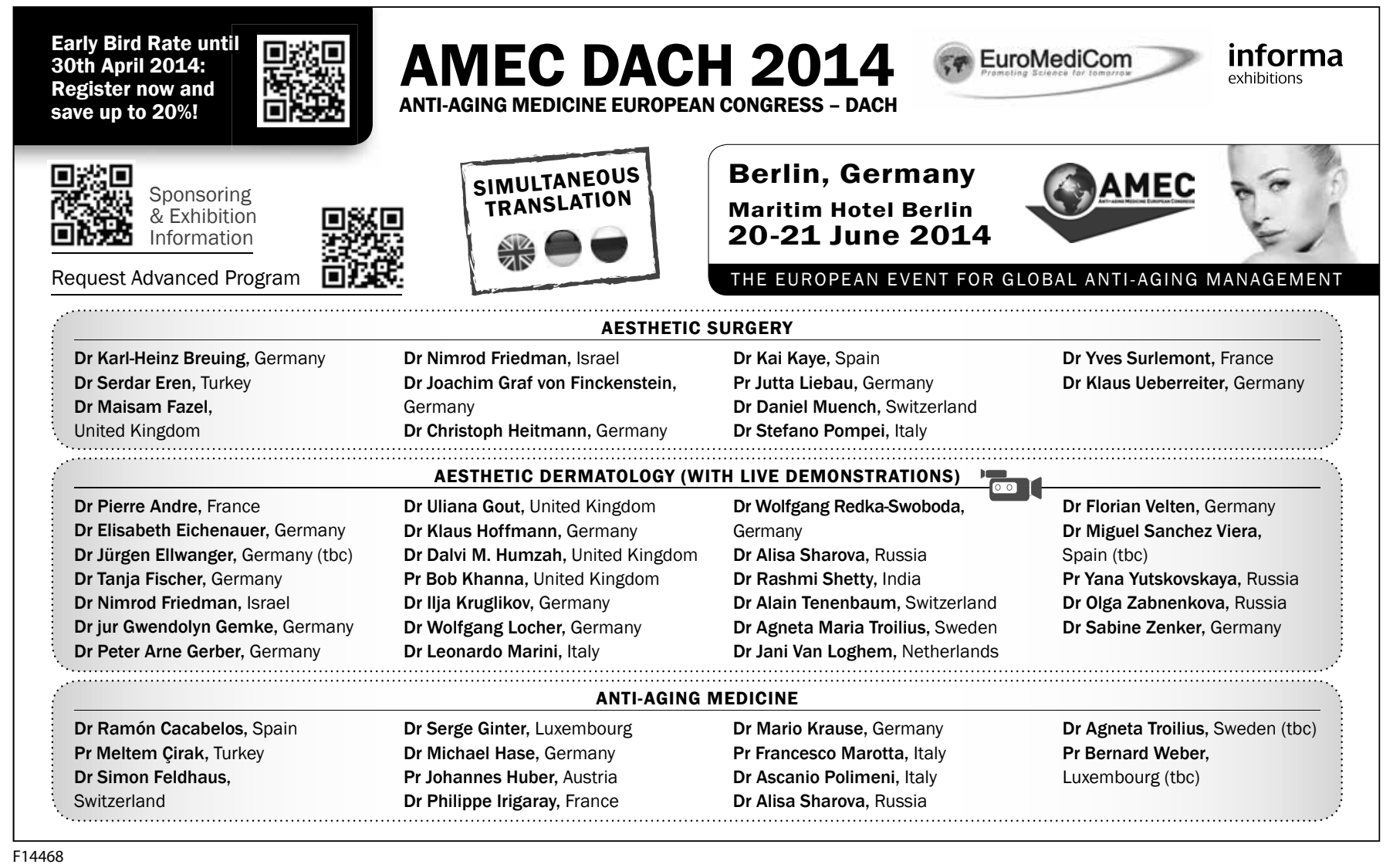

\section{New!}

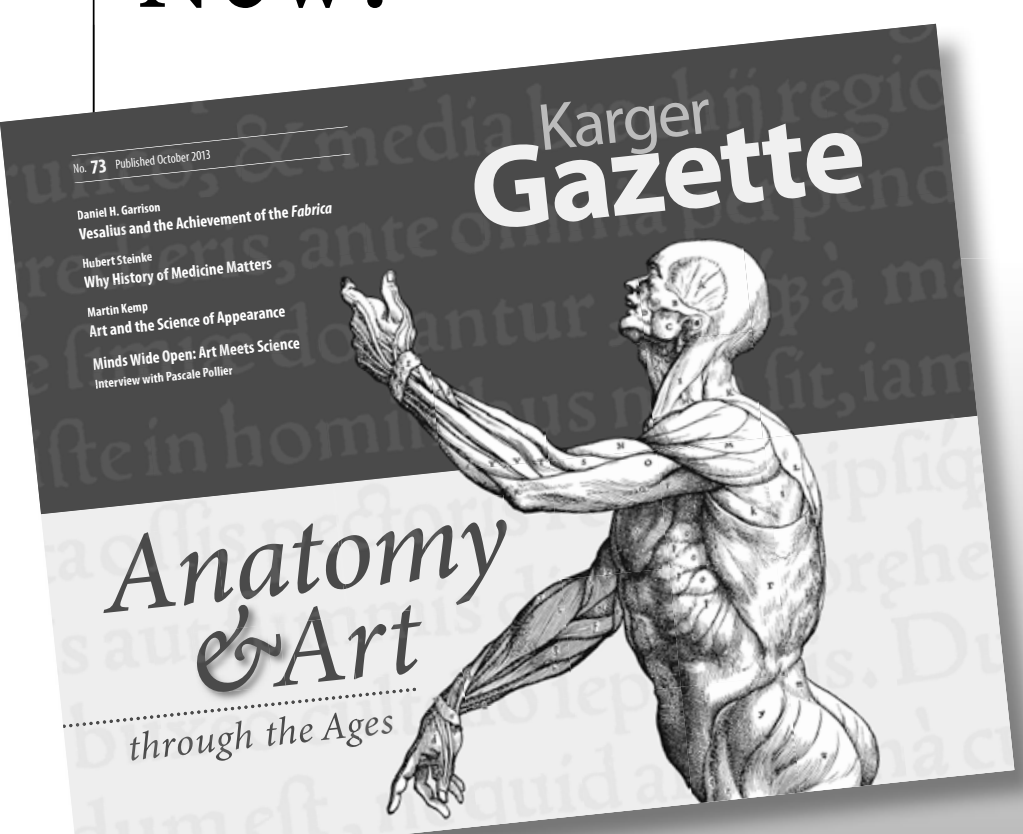

For over 40 years the Karger Gazette has been distributed to a growing audience worldwide. Published once a year in newspaper format, it highlights advances in biomedicine and clinical practice, introduces personalities, portrays research institutes and chronicles milestones in the history of Karger Publishers in a lively and readable style. With invited contributions by experts from all over the world, each issue is devoted to a special topic of current interest.

In the latest issue, read free articles on the famous anatomist Andreas Vesalius, his times and his ground-breaking atlas 'De humani corporis fabrica', and more.

For your free print subscription $\rightarrow$ gazette@karger.com Read it online $\rightarrow$ www.karger.com/gazette
KARGER
S. Karger AG
Medical and Scientific Publishers
Karger Gazette
Allschwilerstrasse 10
CH-4009 Basel
Switzerland
www.karger.com 


\section{9.}

2.-4. Oktober 2014

Kurhaus Wiesbaden

Tagungspräsidenten:

Prot. Dr. med. Ludger Klimek

Prof. Dr. med. Wolfgang Schlenter
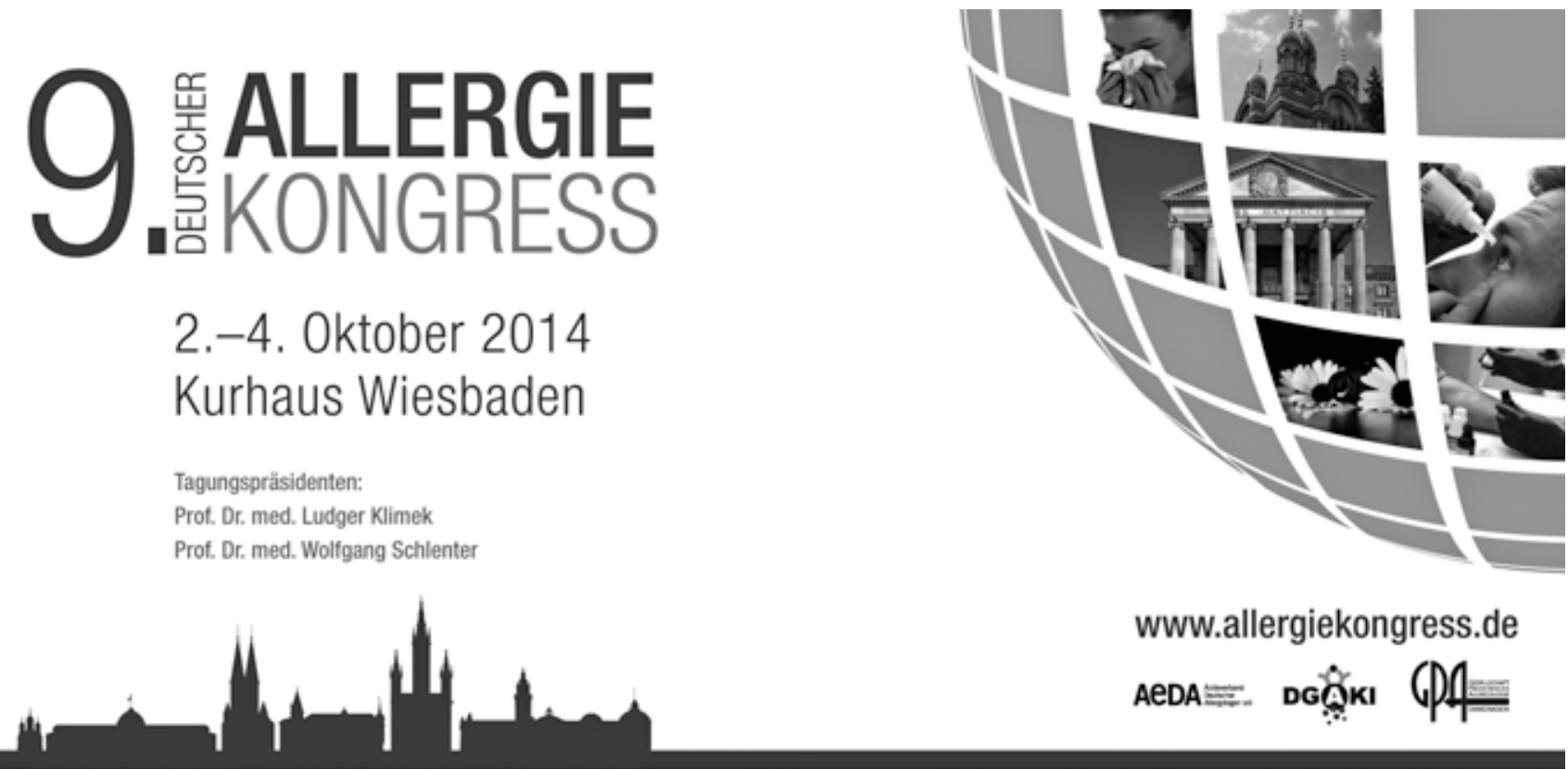

Online-Anmeldung unter www.allergiekongress.de Faxanmeldung bitte zurücksenden an:

FAX: +49 (0) 611204809 - 10

\begin{tabular}{|c|c|c|}
\hline Dauerkarten for dio Gosamntagung & $\begin{array}{l}\text { bes } \\
20.08 .2014\end{array}$ & $\begin{array}{l}a b \\
21.08 .2014\end{array}$ \\
\hline $\begin{array}{l}\text { Migleder } \\
\text { des / der ADA / DQAN / GPA. }\end{array}$ & $170,00 €$ & $220,00 €$ \\
\hline Nichtmitgleder & $220,00 €$ & $270,00 €$ \\
\hline Abstracteinveicher & $170,00 €$ & $170,00 €$ \\
\hline $\begin{array}{l}\text { Pllogebendo, Avathollor/men, Okotropho-logen, } \\
\text { Emitrungswissonechatter" }\end{array}$ & $40,00 €$ & $50,00 €$ \\
\hline Studerten / Doktoranden" & $25,00 €$ & $25,00 €$ \\
\hline
\end{tabular}

\begin{tabular}{|c|c|c|c|}
\hline Tageskarten for don & 02.10 .2014 & 03.10 .2014 & 04.10 .2014 \\
\hline \multicolumn{2}{|c|}{ Mitglodor des / der ADA / DGAN / GPA* } & $90,00 €$ & $110,00 €$ \\
\hline \multicolumn{2}{|l|}{ Nichtrmitgloder } & $110,00 €$ & $140,00 €$ \\
\hline
\end{tabular}

\begin{tabular}{|l|l|l|}
\hline \multicolumn{2}{|l|}{ Rahmenprogramm } \\
\hline$\square$ Alorgio-Party, 02.10.2014 & kostentroi & kostentroi \\
\hline$\square$ Gooclecchatsabend, 03.10 .2014 & $s 0,00 €$ & $70,00 €$ \\
\hline
\end{tabular}

\section{Seminare}

Der Besuch von interaltiven Seminaron effordert eine Vorarmeddung. Bitte wenden Sib sich hiertir an do Kongressorpanisution Td: 449 (0) 611 204 800 - 19 oder per

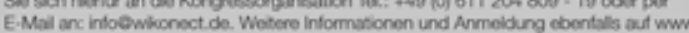

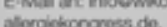

Alo Preise verstehen sich pro Person und ind. 19 \% MwSt

- Nactwois erforderich OMigledsausweis / Schroben Arbeitgeber / Arbeitsvertrag / Studentbescheirigungl - bete an o.g. Farnummer senden

Zahlungs- und Stornierungsbedingungen:

Nach Ethat threr Avmelding vorsenden wir postaligch eine Anmeidebestatigung sowie eine Fiechnung. Die Zahiung der Teindhmegebchren wird mit der Plochnungastellung fallig. Wi

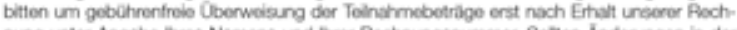
nung urter Angabe itres Namers und frrer Pechnunganummer. Sollten Avidenungen in der Riegistrierung erfordorlch sein, wenden Sie sich bitte per Post, Fax oder E-Mail an die we. konect GmbH. Im Fale von Stornionnoen bis 14 Tage vor Veranstatungsbeginn wid eine

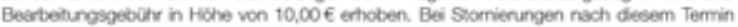

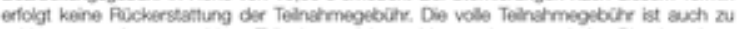
zaklen, wonn ein angemeldeter Toinetmer nicht zur Verarstalung ergcheint. Bitte beachten

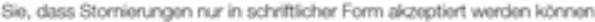

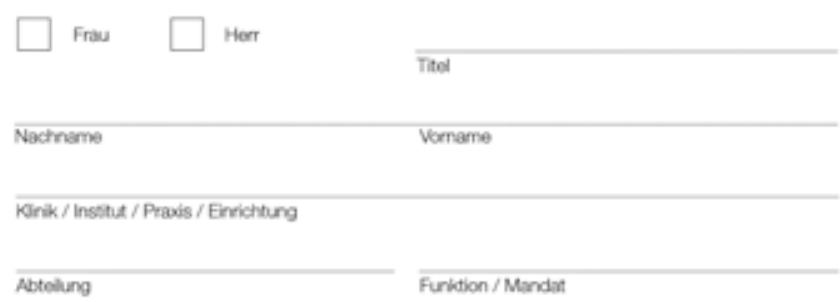

Strabe, N. / Postach

$\overline{\text { PLZ OT }}$ Land

Toboton Far

E-Mail

$\overline{\text { EFN }}$ (Enhertiche Fortbildungsnummer)

Funktion:

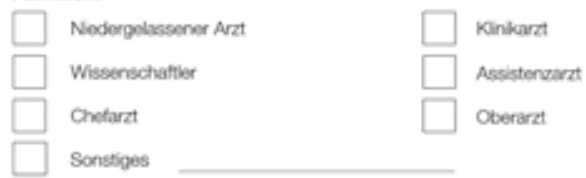

Fachbereich:

$\begin{array}{ll}\square \text { Dermatologie } & \square \text { HNO } \\ \square \text { Padiatrie } & \square \text { Pneumologie } \\ \square \text { Arbeits- und Umweitmediz } & \square \text { Sonstiges }\end{array}$

Newsletter - Allergiekongress

Sie ertalten ausechlioblich Informationen zum Kongress und thre Daten werden nicht an Ditte woiter gogeben.

Eimwilligung: Ja, ich bin dame eirverstanden, aktuele informationen uber den

Alergiekongress per E-Mal-Newsibtter zu erhation.

Hiermit melde ich mich rechtsverbindlich zum Allergiekongress 2014 in Wiesbaden an:

Ot, Dahm, Unterschnt, ggt, Stempel 


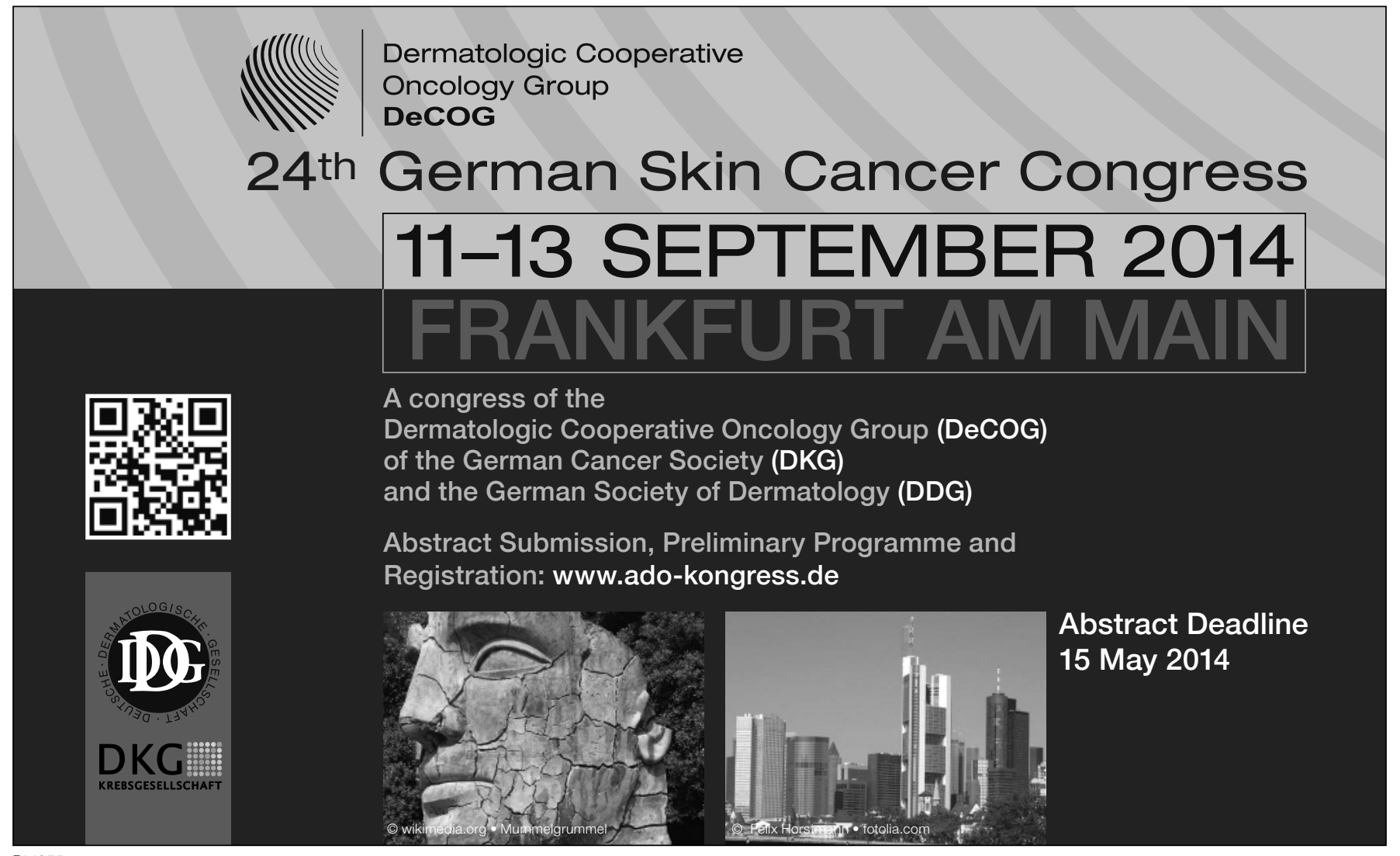

\section{Karger Journals in Dermatology \\ Dermatology \\ Skin \\ Pharmacology ब्चित

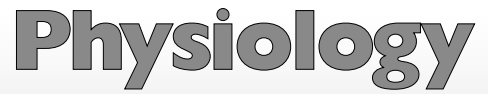 \\ Journal of Pharmacological and Biophysical Research \\ New Journal starting \\ 2014 Online only \\ Dermato pathology Official Journal of the EUROPEAN SOCIETY OF
DERMATOPATHOLOGY}

\section{Case Reports in \\ Dermatology \\ - Open access $•$ Online only $•$ Peer reviewed}

www.karger.com/dermatology

KARGER

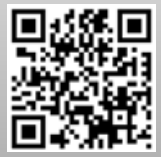




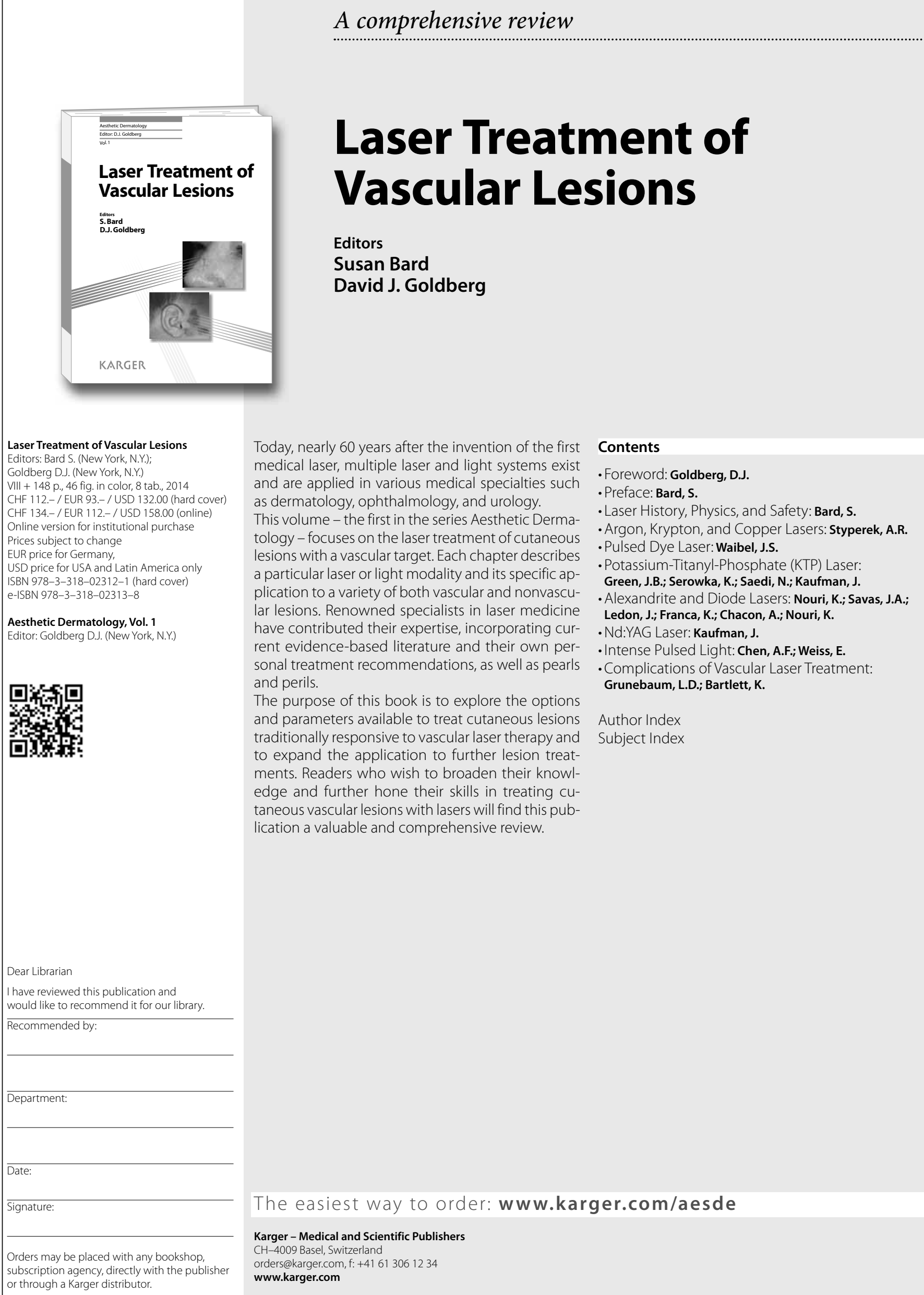




\title{
An essential manual for beginners and senior researchers alike
}

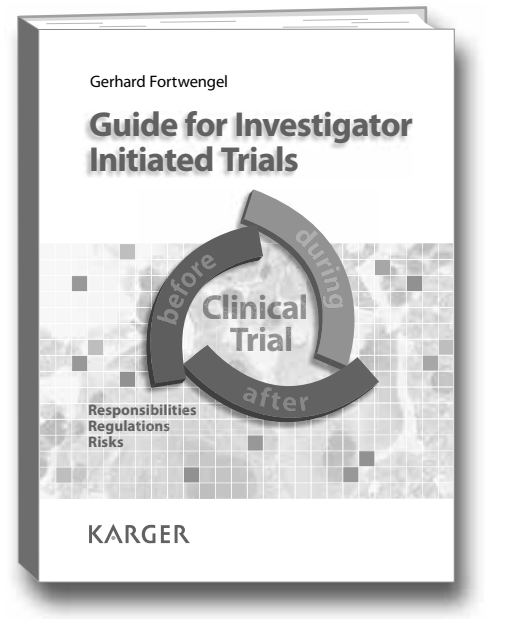

\section{Guide for Investigator Initiated Trials}

\author{
Editor \\ Gerhard Fortwengel
}

In collaboration with:

Isabel Böckler, Rafael Dymek, Sebastian Häckl, Alexander Hahn, Katrin Hertwig, Cynthia Kuhn, Birgit Lindner, Sarah Lütkens, Christoph Neumann, Marcus Paul, Madlen Pomp, Nadja Schachteli

For academic medical faculty unfamiliar with national and international regulations, the prospect of initiating and managing a clinical trial can be intimidating. The development of protocols and case report forms, compliance with regulatory requirements, the monitoring of clinical trials as well as the responsibilities of documentation are just some of the tasks the sponsor-investigator is faced with.

This book covers the entire spectrum of a clinical trial, reviewing the different stages step by step: financial planning, crucial aspects of trial design, the authorization process and, finally, documentation. Moreover, it contains helpful tips, a practical glossary, instructions and a large number of resources related to the relevant regulations and forms conforming to the 'International Conference on Harmonization and Good Clinical Practice' and the European legislation. This makes the publication at hand an essential 'cookbook' for both academic faculty new to clinical trials as well as seasoned sponsors-investigators.

\section{Contents}

- Risk-Benefit Analysis

- Study Types and Study Design

- Investigational Medicinal Products

- Study Protocol

- Case Report Forms

- Financing

- Qualifications, CVs of Site Staff, Training, Delegation of Authority

- EudraCT

- Contracts

- Informed Consent

- Investigator's Brochure/Summary of Product Characteristics

- Insurance

- Health Authority Approval

- Ethics
- Trial Master File, Updating and Archiving

- Documentation

- Data Management

- Screening

- Pharmacovigilance

- Patient Compliance

- Source Data Verification

- Quality

- Monitoring

- Biometry

- Multicentre Trials

- Final Study Report and Publication

- Appendix 1: Common Abbreviations

- Appendix 2: Glossary

- Appendix 3: Health Authority Addresses in the European Area

www.karger.com/documentation

Guide for Investigator Initiated Trials Editor: Fortwengel, G. (Hannover)

$\mathrm{VI}+148$ p., 7 fig., spiral bound, 2011 CHF 49.- / EUR 41.- / USD 58.00 Prices subject to change EUR price for Germany, USD price for USA only ISBN 978-3-8055-9684-8 e-ISBN 978-3-8055-9685-5 $\rightarrow$ Please send: __ copy/ies

Postage and handling free with prepayment

E

Payment:

- Please charge to my credit card

- $\square$ American Express $\square$ Diners $\square$ Eurocard

ᄂ $\square$ MasterCard $\square$ Visa

- Card No.

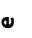

Exp.date

-

- CVV/CVC

( 3 digits in the signature field on the back of Visa and MasterCard)

$\square$ Check enclosed $\square$ Please bill me

Orders may be placed with any bookshop, subscription agency, directly with the publisher or through a Karger distributor.
Fax: +41 613061234

S. Karger AG, P.O. Box, CH-4009 Basel (Switzerland) E-Mail orders@karger.ch,www.karger.com

Name/Address: 


\section{Open access to all articles relevant for the current impact factor: 2.885}

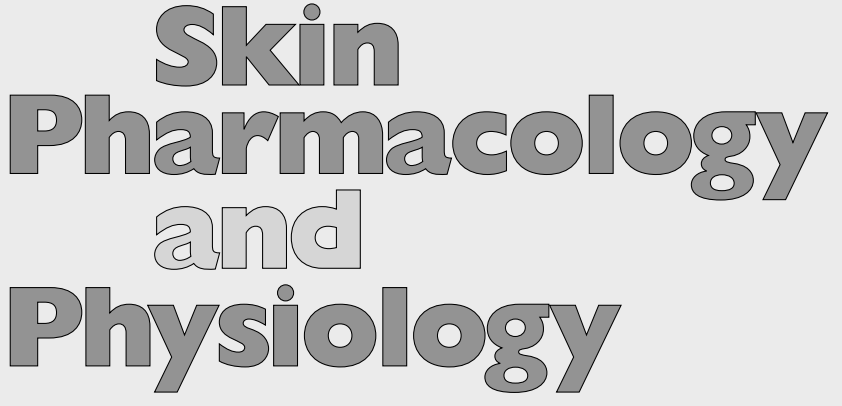

Journal of Pharmacological and Biophysical Research

Editor

J. Lademann, Berlin

Honorary Editors

H.F. Merk, Aachen
Associate Editors

P. Elias, San Francisco, Calif.

J.W. Fluhr, Berlin

H.I. Maibach,

San Francisco, Calif.

H. Mukhtar, Madison, Wisc

G. Nohynek, Asnières

M. Roberts, Brisbane, Qld.

C. Surber, Basel

P. van de Kerkhof, Nijmegen
Official Organ of the International Society of Skin Pharmacology and Physiology

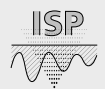

Official Organ of the Society for Dermopharmacy

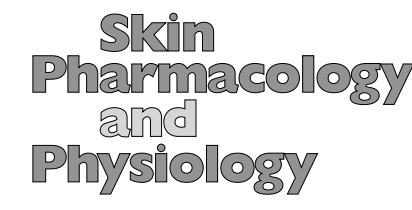

Physiology

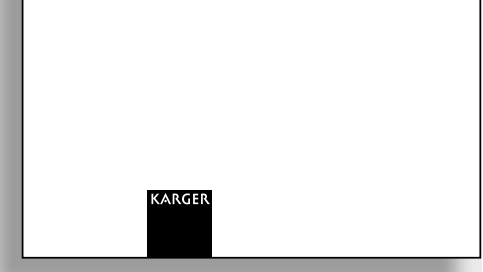

\section{More information at}

\section{www.karger.com/spp}

- Pay-per-View and Subscriber Access to Full Text

- Full Table of Contents

- Full Editorial Board

- Free Abstracts and Selected Articles

- Online Sample Issue

- Submission/Guidelines for Authors

- Subscription Details

- Free Alert Service

- Online Library Recommendation

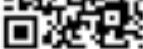

Skin Pharmacology and Physiology

2014: Volume 27

6 issues per volume

Language: English

ISSN 1660-5527 (print)

ISSN 1660-5535 (online)

Listed in bibliographic services, including Current Contents $^{\circledR}$, Pubmed/MEDLINE,

Biological Abstracts

\section{Selected contributions}

- Caffeine's Mechanisms of Action and Its Cosmetic Use: Herman, A. (Warsaw); Herman, A.P. (Jabłonna)

- Drug Delivery with Topically Applied Nanoparticles: Science Fiction or Reality? Lademann, J.; Richter, H.; Meinke, M.C.; Lange-Asschenfeldt, B. (Berlin); Antoniou, C. (Athens); Mak, W.C.; Renneberg, R. (Hong Kong); Sterry, W.; Patzelt, A. (Berlin)

- Current Understanding of Skin Barrier Morphology: Norlén, L. (Stockholm)

- Residual Antimicrobial Effect of Chlorhexidine Digluconate and Octenidine Dihydrochloride on Reconstructed Human Epidermis: Müller, G. (Greifswald); Langer, J. (Berlin); Siebert, J. (Norderstedt); Kramer, A. (Greifswald)

- Passive and lontophoretic Transport through the Skin Polar Pathway: Li, S.K. (Cincinnati, Ohio); Peck, K.D. (Rexburg, Idaho)

- Current Status of Healthy Human Skin Models: Can Histone Deacetylase Inhibitors Potentially Improve the Present Replacement Models? Lemper, M.; Snykers, S.; Vanhaecke, T.; De Paepe, K.; Rogiers, V. (Brussels)

- From the Structure of the Skin Barrier and Dermal Formulations to in vitro Transport Models for Skin Absorption: Skin Research in the Netherlands and in Germany: Windbergs, M.; Hansen, S. (Saarbruecken); Schroeter, A. (Halle-Wittenberg); Schaefer, U.F.; Lehr, C.-M. (Saarbruecken); Bouwstra, J. (Leiden)

- In vitro Skin Permeation and Penetration of Nonivamide from Novel Film-Forming Emulsions: Lunter, D.; Daniels, R. (Tübingen)
In the past decade research into skin pharmacology has developed dramatically with new and promising drugs and therapeutic concepts being introduced regularly. Recent examples include immunosuppressive topicals, and new strategies in the therapy of malignant melanoma and wound healing. New concepts have also been developed in traditional areas of skin therapy and skin care which have led to discussions of issues such as 'cosmeceuticals' in the United States, 'quasi-drugs' in Japan, and the 6th Amendment of the Cosmetic Regulation in the European Union. There are many open questions which reflect the importance of the subject and the need for an international scientific forum where they can be discussed in extenso. Dermatologists, pharmaceutical chemists, pharmacologists, toxicologists, and others interested in the subject are invited to contribute to this exciting project and to submit their best research work for publication. 
Cases and Reviews

97 Systemic Light-Chain Amyloidosis Revealed by Progressive Nail Involvement, Diffuse Alopecia and Sicca Syndrome: Report of an Unusual Case with a Review of the Literature

Renker, T.; Haneke, E. (Berne); Röcken, C. (Kiel); Borradori, L. (Berne)

103 Macular Lymphocytic Arteritis: Three Cases Questioning Its Classification as Primary Lymphocytic Vasculitis

Garcia, C.; Dandurand, M.; Roger, P.; Joujoux, J.-M. (Nîmes); Meunier, L.; Stoebner, P.-E. (Nîmes/Montpellier)

107 Ustekinumab Induces Fast Response and Maintenance of Very Severe Refractory Scalp Psoriasis: Results in Two Greek Patients from the Psoriasis Hospital-Based Clinic Papadavid, E.; Ferra, D.; Koumaki, D.; Dalamaga, M.; Stamou, C.; Theodoropoulos, K.; Rigopoulos, D. (Athens)

112 Cutaneous Actinomycosis Associated with Anti-TNF-Alpha Therapy: Report of Two Cases Breton, A.L. (Lyon); Lamblin, G. (Bron); Pariset, C.; Jullien, D. (Lyon)

115 Systematic Review Focusing on the Excretion and Protection Roles of Sweat in the Skin Peng, Y. (Hong Kong/Guangzhou); Cui, X.; Liu, Y. (Guangzhou); Li, Y. (Beijing); Liu, J.; Cheng, B. (Guangzhou)

121 In vivo Confocal Microscopy Features of Cutaneous Leishmaniasis

Alarcon, I.; Carrera, C.; Puig, S.; Malvehy, J. (Barcelona)

Case Reports

125 Acute Skin Graft-versus-Host Disease with Molecular Features Mimicking Herpes Simplex Virus-Associated Erythema Multiforme: Report of Three Cases

Joseph, R.; Shvartsbeyn, M.; Günay, C.; Akpek, G.; Aurelian, L. (Baltimore, Md.)

130 Allergic Contact Dermatitis from Buprenorphine and Oral Tolerance to Other Opioid Derivatives in Three Patients

Huilaja, L.; Riekki, R. (Oulu); Immonen, A. (Kemi); Tasanen, K. (Oulu)

Letters to Dermatology

132 Epicardial Fat Thickness in Psoriasis Patients

Balta, I. (Ankara); Balta, S.; Ozturk, C. (Eskişehir); Demirkol, S.; Demir, M. (Ankara)

134 Reply

Akyildiz, Z.I.; Nazlı, C. (Izmir)
Original Papers

136 Efficacy and Safety of Propranolol for the Treatment of Infantile Hemangioma: A Presentation of Ninety-Nine Cases

Sagi, L. (Tel Aviv); Zvulunov, A. (Petach Tikva/Beer Sheva); Lapidoth, M.; Ben Amitai, D. (Tel Aviv/Petach Tikva)

145 Prospective Clinical and Epidemiologic Study of Vulvar Lichen Sclerosus: Analysis of Prevalence and Severity of Clinical Features, together with Historical and Demographic Associations

Virgili, A.; Borghi, A.; Toni, G.; Minghetti, S.; Corazza, M. (Ferrara)

152 Impact of TNF Haplotypes in the Physical Course of Acne Vulgaris

Grech, I.; Giatrakos, S.; Damoraki, G. (Athens); Kaldrimidis, P. (Piraeus); Rigopoulos, D.; Giamarellos-Bourboulis, E.J. (Athens)

158 Pilot Study of 19 Patients with Severe Pemphigus: Prophylactic Treatment with Rituximab Does Not Appear to be Beneficial

Gregoriou, S.; Giatrakou, S.; Theodoropoulos, K.; Katoulis, A.; Loumou, P.; Toumbis-Ioannou, E.; Papadavid, E.; Avgerinou, G.; Stavrianeas, N.; Rigopoulos, D. (Athens)

166 Randomized, Within-Patient, Clinical Trial Comparing Fluorine-Synthetic Fiber Socks with Standard Cotton Socks in Improving Plantar Pustulosis

Cazzaniga, S. (Bergamo); Lo Scocco, G.; Schincaglia, E. (Prato); Mercuri, S.R. (Milan); Chimenti, S.; Saraceno, R. (Rome);

Naldi, L. (Bergamo)

172 Use of Selective Serotonin Reuptake Inhibitors in the Treatment of Burning Mouth Syndrome

Fleuret, C.; Le Toux, G.; Morvan, J.; Ferreira, F.; Chastaing, M.; Guillet, G.; Misery, L. (Brest)

177 Urgent Consultations at the Dermatology Department of Basel University Hospital, Switzerland:

Characterisation of Patients and Setting - A 12-Month Study with 2,222 Patients Data and Review of the Literature

Ruzza, N.; Itin, P.H. (Basel); Beltraminelli, H. (Basel/Berne)

183 Molecular Analysis of a Series of Israeli Families with Comèl-Netherton Syndrome

Israeli, S.; Sarig, O.; Garty, B.Z. (Tel Aviv); Indelman, M.; Bergman, R. (Haifa); Sprecher, E.; Goldberg, I. (Tel Aviv)

189 ILDS Newsletter No. 31

Cover illustration

For details see Vol. 226, No. 4, 2013, p. 345, Fig. 6. 